\title{
STUDI KELAYAKAN USAHA PEMBIBITAN IKAN LELE DUMBO DI KELURAHAN KANDANG KECAMATAN KAMPUNG MELAYU KOTA BENGKULU
}

\author{
${ }^{1}$ Bobi Habibullah, ${ }^{2}$ Elni Mutmainnah, ${ }^{3}$ Romzi \\ ${ }^{1,2}$ Prodi Agribisnis Faperta UMB, ${ }^{3}$ PBT Dinas Pertanian provinsi Bengkulu \\ 1bobihabibullah355@gmail.com \\ mamirizki_2009@yahoo.co.id \\ 3rizki25riqa@gmail.com
}

\begin{abstract}
ABSTRAK
Latar belakang penelitian ini di dasarkan kepada permintaan ikan air tawar yang cukup tinggi di wilayah kota Bengkulu. Selain itu juga didukung oleh sumber daya alam dan potensi area perairan darat di kota Bengkulu yang mendukung untuk dikembangkan sebagai usaha budidaya perairan darat. Ikan Lele merupakan makanan yang sangat disukai oleh masyarakat karena rasanya yang gurh dan bernilai gizi yang tinggi. Tujuan dari penelitian ini adalah untuk melihat kelayakan usaha budidaya Ikan Lele secara finansialnya. Lokasi penelitian dilakukan di Desa Kandang Kecamatan Kampung Melayu Kota Bengkulu. Responden dalam penelitian ini adalah seluruh petani budidaya Ikan lele yang berada di sepanjang jalan di Desa Kandang Kota Bengkulu. Berdasarkan hasil penelitian menunjukkan bahwa usaha budidaya ikan Lele di Desa Kandang layak untuk diusahakan berdasarkan dengan nilai keuntungan sebesar Rp. 53.113.067,80. Secara finansial usaha budi daya Ikan Lele Dumbo ini masih layak dilakukan sampai dengan 10 tahun ke depan berdasarkan nilai NPV positip sebesar Rp. 143.622.994,00 sampai dengan tingkat suku bunga 19\% yang lebih besar dari nilai suku bunga yang berlaku (7\%). Nilai Net Benefit rasio sebesar 1,62 .
\end{abstract}

Keywords: catfish, breeding, feasibility

\section{PENDAHULUAN}

Latar belakang penelitian ini di dasarkan kepada permintaan ikan air tawar yang cukup tinggi di wilayah kota Bengkulu. Selain itu juga didukung oleh sumber daya alam dan potensi area perairan darat di kota Bengkulu yang mendukung untuk dikembangkan sebagai usaha budidaya perairan darat. Ikan Lele merupakan makanan yang sangat disukai oleh masyarakat karena rasanya yang gurh dan bernilai gizi yang tinggi. Lele (Clarias) adalah salah satu jenis ikan yang bergizi tinggi, sehingga mendukung asupan masyarakat untuk konsumsi ikan yang kaya akan omega 3. Lele setidaknya mengandung $17-37 \%$ protein, $4,8 \%$ lemak, $1,2 \%$ mineral, $1,2 \%$ vitamin, dan 
75,1 air. Manfaat lele bagi masyarakat secara umum dapat menjadi sumber protein hewani yang cukup tinggi, kaya akan phosphor, rendah lemak. Lele merupakan jenis ikan yang digemari masyarakat, dangan rasa yang lezat, daging empuk, duri teratur, dan dapat disajikan dalam berbagai macam menu masakan. Walaupun sebelum tahun 1990an lele belum begitu populer sebagai makanan lezat, namun oleh warungwarung pecal lele menjadi makanan populer yang merakyat dan menyebar kemana-mana. Harga kuliner lele juga cukup terjangkau (Soares, 2011).

Kelurahan kandang kecamatan kampung melayu kota bengkulu merupakan lokasi pembenihan ikan lele dumbo. Kelurahan kandang dalam upaya peningkatan produksi budidaya perikanan diharapkan dapat menjalankan fungsinya sebagai penyedia indukan dan benih unggul khususnya untuk jenis ikan lele dumbo, sehingga kebutuhan akan benih yang bermutu dengan harga yang terjangkau dapat dipenuhi. Usaha pembenihan ikan lele dumbo diharapkan dapat berkembang menjadi besar yang pada akhirnya mampu meningkatkan tingkat kesejahteraan para pembudidaya dan sekaligus meningkatkan kesejahteraan masyarakat bengkulu sebagai usaha melalui kecukupan gizi dan protein yang bersumber dari

ikan lele. Produksi ikan lele di kecamatan kampung melayu meningkat sejak tahun 2013 - 2018, peningkatan tersebut dapat dilihat pada tabel 1 dibawah ini.

Tabel 1. Produksi dan harga ikan lele di kecamatan kampung melayu.

\begin{tabular}{|c|c|c|c|}
\hline NO & Tahun & $\begin{array}{c}\text { Produksi } \\
(\mathrm{Kg})\end{array}$ & $\begin{array}{c}\text { Harga Rata-rata } \\
\text { Konsumsi } \\
(\mathrm{Rp} / \mathrm{Kg})\end{array}$ \\
\hline 1 & 2013 & 580.000 & 16.000 \\
\hline 2 & 2014 & 600.000 & 18.000 \\
\hline 3 & 2015 & 625.000 & 22.000 \\
\hline 4 & 2016 & 670.000 & 24.000 \\
\hline 5 & 2017 & 700.000 & 25.000 \\
\hline 6 & 2018 & 760.000 & 23.000 \\
\hline
\end{tabular}

Sumber : Dinas Kelautan dan Perikanan Kota Bengkulu (DKP), 2018.

Berdasarkan tabel 1 diatas produksi ikan lele di kecamatan kampung melayu kota bengkulu dari tahun 2013 sebesar $580.000 \mathrm{Kg}$, meningkat sampai tahun 2018 sebesar 760.000 Kg. Dimana setiap tahunnya mengalami peningkatan karena konsumsi ikan lele di provinsi bengkulu bertambah terkhususnya di kota bengkulu untuk memenuhi pasokan ikan lele maka kelurahan kandang merupakan salah satu lokasi pembibitan ikan lele yang sangat 
potensi untuk dikembangkan. Kegiatan ini didukung oleh kondisi sumber daya alam Kelurahan Kandang yang memiliki wilayah yang luas dengan sumber daya manusia yang cukup besar untuk kegiatan usaha ini.

\section{METODE PENELITIAN}

Metode penelitian ini yang digunakan adalah sensus, data yang dikumpulkan berupa data primer dan data sekunder. Data primer diperoleh melalui survei lokasi dan wawancara melalui kuesioner. Untuk menganalisis keuntungan usaha pembibitan ikan lele digunakan fungsi keuntungan sebagai berikut :

$$
\begin{aligned}
J I & =\mathrm{TR}-\mathrm{TC} \\
\mathrm{TR} & =\mathrm{Q} \cdot \mathrm{Pq} \\
\mathrm{TC} & =\mathrm{FC}+\mathrm{VC}
\end{aligned}
$$

Keterangan :

$J I \quad=$ Keuntungan

$\mathrm{TR}=$ Total Revenue/Penerimaan Total

$\mathrm{TC}=$ Total Cost/Biaya Total

$\mathrm{Q}=$ Jumlah Bibit lele yang diproduksi

$\mathrm{Pq}=$ Harga Bibit lele

Dalam Nurmalina, dkk (2009), analisis kelayakan finansial dilakukan dengan menggunakan kriteria investasi, yaitu NPV, IRR, Net B/C dan Payback Period. Analisis kelayakan finansial bertujuan untuk menilai apakah investasi ini layak atau tidak untuk dijalankan dilihat dari aspek keuangan.

\section{a. Net Present Value}

Net Present Value (NPV) usaha budidaya buah naga adalah selisih present value (PV) arus benefit dengan PV arus cost. NPV menunjukkan manfaat bersih yang diterima usaha budidaya ikan lele dumbo selama umur bisnis pada tingkat discount rate tertentu. NPV secara matematis dapat dirumuskan sebagai berikut :

$\mathrm{NPV}=\sum_{\mathrm{t}=0}^{\mathrm{t}=\mathrm{n}}(\mathrm{Bt}-\mathrm{Ct})(\mathrm{DF})$

Dimana:

NPV $=$ Net Present Value atau Nilai Sekarang (Rp)

Bt $=$ Benefit pada tahun ke $\mathrm{t}(\mathrm{Rp})$

$\mathrm{Ct}$ = biaya pada tahunke $\mathrm{t}(\mathrm{Rp})$

$\mathrm{DF}=$ Tingkat bunga (discount factor) $(\%)$

$\mathrm{n} \quad=$ Lamanya periode waktu (Tahun)

Kreteria kelayakan yaitu :

NPV > 0, artinya usaha budidaya ikan lele dumbo dinyatakan layak untuk dilaksanakan.

$\mathrm{NPV}=0$, artinya usaha budidaya kan lele dumbo mampu mengembalikan sebesar social opportunity costfaktor produksi modal.

NPV $<0$, artinya usaha budidaya ikan lele dumbo tidak layak dilaksanakan.

2. Internal Rate of Return 
Internal Rate of Return (IRR) adalah nilai discount rate yang membuat NPV usaha budidaya ikan lele Dumbo benilai nol. IRR adalah tingkat rata-rata keuntungan intern tahunan bagi perusahaan yang melakukan investasi dan dinyatakan dalam satuan persen. IRR secara sistematis dapat dirumuskan sebagai berikut :

$\mathrm{IRR}=i 1+\left[\frac{N P V 1}{N P V 1-N P V 2} \times(i 2-i 1)\right]$

Keterangan :

$i 1=$ discount rate yang

menghasilkan NPV positif

i2 = discount rate yang

menghasilkan NPV negatif

NPV 1 = NPV yang bemilai positif

NPV 2 = NPV yang bemilai negatif

Kriteria yaitu :

- Jika IRR > tingkat discount rate, maka usaha budidaya buah naga layak

- Jika IRR = tingkat discount rate, maka usaha budidaya Ikan lele Dumbo tidak menguntungkan namun juga tidak merugikan

- Jika IRR < tingkat discount rate, maka usaha budidaya Ikan lele Dumbo tidak layak.

3. Net Benefit Cost Ratio
Net Benefit Cost Ratio (Net B/C) merupakan angka perbandingan antara jumlah present value yang positif (sebagai pembilang) dengan jumlah present value yang negatif (sebagai penyebut). Secara matematis dapat dituliskan sebagai berikut :

Net $\mathrm{B} / \mathrm{C}=\frac{\sum_{t=1}^{n} \frac{B t-C t}{(1=i)^{t}}}{\sum_{t=1}^{n} \frac{B t-C t}{(1=i)^{t}}} \rightarrow \frac{\text { Untuk } B t-C t>0}{\text { Untuk } B t-C t<0}$

Keterangan :

$\mathrm{Bt}=$ manfaat pada tahun $\mathrm{t}$

$\mathrm{Ct}=$ biaya pada tahun $\mathrm{t}$

$\mathrm{N}=$ umur bisnis budidaya lele dumbo (tahun)

$\mathrm{i}=$ discount rate $(\%)$

$\mathrm{t}=$ tahun

Kriteria kelayakan yaitu :

- $\quad$ Jika Net $\mathrm{B} / \mathrm{C}=1$, maka NPV $=0$, usaha budidaya Lele Dumbo dikatakan layak, namun keuntungan yang diperoleh hanya sebesar opportunity cost nya.

- $\quad$ Jika Net $\mathrm{B} / \mathrm{C}>1$, maka NPV >0, usaha budidaya Ikan Lele Dumbo dikatakan layak.

- $\quad$ Jika Net $\mathrm{B} / \mathrm{C}<1$, maka NPV $<0$, usaha budidaya Ikan Lele Dumbo dikatakan tidak layak.

HASIL DAN PEMBAHASAN

Biaya Produksi dan Pendapatan 
Biaya produksi terdiri dari biaya tetap dan biaya variabel, biaya tetap terdiri dari harga lahan, pajak lahan dan penyusutan alat sedangkan biaya variabel terdiri dari sarana produksi (saprodi) dan tenaga kerja. Total biaya investasi yang dibutuhkan untuk usaha pembibitan ikan lele Dumbo sebesar Rp. 214.600.333,33 atau rata-rata membutuhkan investasi sekitar 35 juta karena biaya yang dikeluarkan untuk investasi pertama

Tabel 4. Rekapitulasi hasil analisis usaha pembibitan ikan lele dumbo satu priode produksi

\begin{tabular}{|c|l|r|}
\hline NO & \multicolumn{1}{|c|}{ Uraian } & Jumlah (Rp) \\
\hline$(1)$ & \multicolumn{1}{|c|}{$(2)$} & $(3)$ \\
\hline 1 & Biaya Investasi & $\mathbf{2 1 4 . 6 0 0 . 3 3 3 , 3 3}$ \\
\hline 2 & Biaya variabel & $\mathbf{4 . 5 8 6 . 1 6 0 , 0 0}$ \\
\hline 3 & Total biaya sebelum bunga bank (1+2) & $\mathbf{1 . 2 7 1 . 2 8 1 , 6 6}$ \\
\hline 4 & Bungah pinjaman 0,58\% & $\mathbf{2 2 0 . 4 5 7 . 7 7 4 , 9 9}$ \\
\hline 5 & Total biaya (3+4) & $\mathbf{6 . 8 7 5 . 0 0 0 , 0 0}$ \\
\hline 6 & Penerimaan & \multicolumn{1}{|c|}{} \\
\hline & ( Produksi 92 kg x harga Rp.75.000/kg) & \\
\hline
\end{tabular}

Sumber : Data primer diolah, 2019 dibutuhkan untuk biaya variabel seperti indukan lele, sewa tempat, tenaga kerja dan pakan. Dengan asumsi harga jual $\mathrm{Rp} 75.000 / \mathrm{kg}$ dan rata-rata produksi $92 \mathrm{Kg} /$ produksi maka diperkirakan akan memperoleh keuntungan sebesar Rp. 6.875.000,00 per produksi. 
suatu proyek dilaksanakan dengan berhasil. Proyek yang dimaksudkan disini biasanya merupakan proyek investasi. Analisis kelayakan proyek memiliki tujuan antara lain untuk memperbaiki pemilihan investasi. Selain untuk memperbaiki pemilihan investasi, analisis kelayakan proyek juga bertujuan menghindari ketelanjuran penanaman modal yang terlalu besar untuk kegiatan yang ternyata tidak menguntungkan (Husnan dan Suwarsono, 2000). Dalam rangka mencari suatu ukuran yang menyeluruh sebagai dasar penerimaan/penolakan suatu usaha maka di gunakanlah suatu investment criteria. Investment criteria ini merupakan alat ukur yang menentukan apakah suatu usaha layak dilaksanakan atau tidak layak untuk dilaksanakan.

Hasil perhitungan kelayakan usaha Pembibitan Ikan Lele Dumbo diperoleh sebagai berikut :

\begin{tabular}{|c|c|c|c|c|}
\hline No & \multicolumn{1}{|c|}{ Uraian } & NPV (7\%) & Net B/C & IRR (7\%) \\
\hline$(1)$ & $(2)$ & $(3)$ & $(4)$ & $(5)$ \\
\hline 1 & Keadaan normal & $143.622 .994,00$ & 1,62 & $19,42 \%$ \\
\hline 2 & Biaya naik 25\% & $92.554 .808,10$ & 1,39 & $16,29 \%$ \\
\hline 3 & Penerimaan turun 10\% & $85.678 .446,70$ & 1,37 & $14,62 \%$ \\
\hline
\end{tabular}

Sumber : Data primer diolah, 2019

Berdasarkan tabel di atas dapat dilihat bahwa dalam keadaan normal (sesuai dengan yang diproyeksikan) NPV positif Rp. 143.622.994,00., Net B/C = 1,62 dan IRR $=19,42 \%$ yang jauh diatas persentase bunga pinjaman $(7 \%$ per tahun). Hal ini memberikan arti bahwa usaha ini sangat layak untuk dilaksanakan.
Analisis sensitivitas dilakukan pada arus kas dari masing-masing alternatif sistem pendapatan. Analisis sensitivitas didapatkan dari penilaian terhadap perubahan variabel-variabel investasi seperti perubahan nilai tingkat suku bunga, biaya investasi awal dan harga penjualan bibit ikan lele. Hasil sensitivitas menunjukan bahwa proyek ini sangat menguntungkan dan layak 
terhadap biaya naik $25 \%$ dan penerimaan turun $10 \%$ keadaan ini terlihat bahwa NPV positif, Net B/C > 1 dan IRR > 7\% atau lebih besar dari persentase bunga pinjaman (7\% per tahun). Pada analisis sensitivitas terhadap peningkatan biaya investasi menunjukan alternatif sistem jual tetap layak ketika biaya investasi meningkat sebesar $25 \%$ dari biaya investasi semula dengan nilai NPV menunjukan Rp. 92.554.808,10., Net B/C $=1,39$ dan IRR $=16,29 \%$ yang jauh diatas persentase bunga pinjaman $(7 \%$ pertahun) artinya bahwa proyek ini layak untuk diusahakan. Sedangkan pada analisis sensitivitas terhadap penurunan benefit (penerimaan) menunjukan alternatif sistem jual tetap layak ketika benefit turun menjadi $10 \%$ dari penerimaan semula dengan nilai NPV menunjukan Rp. 85.678.446,70., Net B/C $=1,37$ dan IRR $=14,62 \%$ yang jauh diatas persentase bunga pinjaman $(7 \%$ pertahun). Hal ini menunjukakan bahwa

\section{KESIMPULAN}

1. Dari perhitungan diperoleh pendapatan bersih usaha pembibitan ikan lele dumbo mengalami kerugian pada produksi pertama di tahun pertama sebesar Rp. (176.583.736,67). Dan untuk tahun ke-2 sampai tahun ke-10 usaha proyek ini layak untuk diusahakan. Adapun alasan dilakukan analisis sensitivitas yang dapat menyebabkan biaya naik $25 \%$ dan penerimaan turun $10 \%$ dan juga tingkat Shadow Price sebesar 5\% ( harga bayangan) ditiap-tiap tahun selanjutnya yaitu :

- Adanya cost overrun, kenaikan biaya-biaya seperti biaya bahan baku, biaya peralatan dan produksi.

- Penurunan produktifitas.

- Inflasi, terjadi karena peningkatan harga-harga secara umum dan terus menerus

- faktor-faktor uncontrolable seperti banjir, terbakar, dan bencana alam lainnya yang diluar jangkauan manusia.

pembibitan ikan lele dumbo ini mengalami keuntungan rata-rata sebesar Rp. 53.113.067,80.

2. Usaha pembibitan ikan lele dumbo dikelurakan kandang kecamatan kampung melayu kota bengkulu layak diusahakan sampai 10 tahun ke depan dengan nilai Net Present 
Value positif Rp. 143.622.994,00., Net $\mathrm{B} / \mathrm{C}=1,62$ artinya $>1$ dan tingkat Internal Rate of Return = $19,42 \%$.

Tingkat sensitivitas usaha masih layak diusahakan sampai dengan kenaikan biaya 25\% Net Present Value positif Rp. 92.554.808,10., Net $\mathrm{B} / \mathrm{C}=1,39$ artinya $>1$ dan Internal Rate of Return $=16,29 \%$ Dan dalam keadaan penerimaan turun $10 \%$ Net Present Value positif Rp. 85.678.446,70., Net $\mathrm{B} / \mathrm{C}=1,37$ artinya $>1$ dan Internal Rate of Return $=14,62 \%$. Dengan tingkat bunga pada saat penelitian $7 \%$ jadi usaha pembibitan ikan lele dumbo dikelurahan kandang kecamatan kampung melayu layak untuk diusahakan.

\section{SARAN}

Diharapkan bagi para petani usaha pembibitan ikan lele di kelurahan kandang kota bengkulu lebih meningkatkan usahanya. kedepan yaitu perlunya kerjasama dengan pemerintah agar dapat memberikan peluang pengembangan usaha baik dari segi input maupun output.

\section{DAFTAR PUSTAKA}

Binei, M. Manoppo, V. Aling, D. 2016. Analisis Finansial Usaha
Pembenihan Ikan Lele Sangkuriang (Clarias Gariepinus) di Desa Tateli Dua Kecamatan Mandolang Kabupaten Minahasa Provinsi Sulawesi Utara. Jurnal Akulturasi. Fakultas Perikanan dan Ilmu Kelautan Universitas Sam Ratulangi, Manado. Vol. 4 No. 8.

Ibrahim, Y. 2009. Studi Kelayakan Bisnis. Jakarta : Rineka Cipta. Hlm. 249.

Khairuman, Amri. K, 2011. Pembenihan Lele 21 Hari Balik Modal. PT Agro Media Pustaka. Jakarta.

Nurmalina R, Sarianti T, Karyadi A. 2009. Studi Kelayakan Bisnis. Departemen Agribisnis Fakultas Ekonomi dan Manajemen Institut Pertanian Bogor, Bogor.

Profil Dinas Kelautan dan Perikanan Provinsi Kota Bengkulu 2018.

Soares, T. 2011. Kajian Usaha Benih Ikan Lele Di Desa Tulungrejo Kecamatan Pare Kabupaten Kediri. Skripsi. Fakultas Pertanian Universitas Pembangunan Nasional Jawa timur. Surabaya. 89 Hal.

Supare, D. 2017. Analisis Usaha Penggilingan Padi di Kecamatan Armajaya Kabupaten Bengkulu Utara. Skripsi Mahasiswa S1 Fakultas Pertanian. Universitas Muhammadiyah bengkulu, Tidak di Publikasikan. 
ISSN No 2086-7956 E-ISSN No 2615-5494

Jurnal AGRIBIS Vol 11. No. 2 Juli 2020 Hal 1537-1546 